УДК 130.3

doi: 10.32620/gch.2019.1.06

Більчук Н. Л., Більчук А. В.

\title{
ОСЯГНЕННЯ ФЕНОМЕНА СМЕРТІ ЯК ЕКЗИСТЕНЦЙНА ІДЕНТИЧНІСТЬ ОСОБИСТОСТІ
}

У статті розглянуто проблему усвідомлення феномена смерті як фактора аналізу власної ідентичності. Визначено роль осягнення власної смертності «тут-і-зараз» як чинника актуалізації екзистенційного буття особистості й формування індивідуально неповторної самості як стохастичної системи за допомогою введення поняття "Яфрактал».

Ключові слова: екзистенційна смерть, самість, «Я-фрактал», присутність.

В статье представлена проблема осознания феномена смерти как фактора анализа собственной идентичности. Определена роль осмысления собственной смертности как условия актуализаџии экзистенциального бытия личности и формирования индивидуально неповторимой самости как стохастической системы с помощью введения понятия "Яфрактал».

Ключевые слова: экзистенциальная смерть, самость, «Я-фрактал», присутствие.

The article deals with the problem of understanding the phenomenon of death as a factor of self-identity analysis. The role of comprehension of own mortality «here-and-now» as the factor of actualization of the existential existence of the personality and the formation of individually unique self as a stochastic system by means of the introduction of the concept of «I-fractal» is determined.

Keywords: existential death, self, «I-fractal», presence.

Таємниия смерті оберігає людину навіть перед тим, як вона навчиться зберігати ї̈ сама.

Ж. Дерріда

Найбільша таємниця всесвіту - це таїнство народження (появи) i смерті (зникнення) людини. Проте не тому, що людина «єдина розумна істота» й тому посідає центральне місце у світі. Вона $є$ неповторною, бо єдина, чия сутність не визначається фактом народження («бути людиною» не тотожне «належати до біологічного виду»). Саме трансцендування, вихід за межі біологічного й відкриває (формує) екзистенційний вимір існування особистості, «людяне в людині». Вона як той мандрівник, який ще тільки має (чи може?!) відшукати дорогу - дорогу до себе, народитися вдруге, тобто ідентифікувати себе як людину, особистість. На цьому довгому (чи ні) шляху вона знов-таки єдина, хто знає, чим він завершиться; незнамо коли, незнамо як, але обов'язково одним і тим самим - смертю. Життя - це рух до смерті й у буквальному, й у метафоричному сенсі. Власне життя та власна смерть дві нерозривні протилежності, що супроводжують людину всюди й завжди: одна - як те, що є, друга - як те, на що очікують (що буде). I хоча, як зауважує Епікур, із власною смертю ми ніколи не зустрічаємося (бо тоді нас уже немає), вона завжди 
попереду, але можемо «зазирнути їй у вічі», «приготуватися». Саме осягнення власної смертності зумовлює й ставлення до життя; і навпаки, визначення сутності (якості) життя зумовлене поглядом на смерть.

Сучасна ситуація висвітлює все більш складну структуру внутрішнього світу особистості. Якщо класична філософська парадигма прагнула до визначення сутнісних засад людини, які зумовлюють цілісність і визначеність іï внутрішнього світу, оперуючи поняттями «особистість», «індивід», то постмодерністська програма розглядає людину як сукупність эiі ідентифікацій, феноменів самоусвідомлення. Сучасна людина «розсипається» на безліч «масок та ролей», «грає», «примірює» різні самості так, начебто й не потребує якоїсь визначеності (дефініцій). Але ж існує така мить, коли вона стане визначеною, якоюсь певною. Це мить «зустрічі» зі смертю. У цьому сенсі людина постає «невизначено-визначеною»: поки вона жива, про неї нічого невідомо достеменно, а коли прийде смерть, вона вже нічого не може змінити. Життя складається 3 безлічі подій, феноменів існування, «одиничностей», «тимчасових самостей», які разом мають об'єднатися в єдину цілісність. Кожен із «тут-і-зараз» феноменів життя може стати визначальним для особистісного Я, змінити його.

У цьому сенсі самість може розглядатися за аналогією з фракталом - наочною демонстрацією систем «хаотичної» складності, які перебувають у нескінченному становленні й виражають незавершений характер соціокультурних феноменів, а отже, $\epsilon$ стохастичними системами. Особливістю фрактала $\epsilon$ те, що він становить сукупність елементів, які за структурою аналогічні самій цілісній системі. При цьому зміни в розвитку одного елемента можуть призвести до змін у структурі всього фрактала. Тому філософська рефлексія осягнення феномена власної смерті й смертності як умови актуалізації й осмислення життя, надання йому сенсу 3 урахуванням особливостей сьогодення $\epsilon$ особливо актуальною. Метою статті $\epsilon$ розкриття ролі усвідомлення феномена смерті як «тут-і-зараз» на визначення ідентичностей соціального суб'єкта й формування єдиної індивідуально неповторної Я-самості як стохастичної системи.

За часів становлення самосвідомості людства філософська рефлексія неодноразово зверталася до аналізу феномена смерті й ставлення людини до неї, зазначаючи, що саме вирішення цієї проблеми визначає сутнісну особливість кожної епохи. Як зауважує О. Шпенглер, нове ставлення до смерті породжує й нову культуру. Становлення й осмислення феномена смерті (ставлення до смертності взагалі) постають одним із чинників визначення ідентичності суб'єкта на різних рівнях - індивідуальному, соціальному, національному, історичному, культурному. Це нібито символічний код, розшифрування якого розкриває особливості цілої епохи, культурної традиції, окремої особистості.

Ще з часів Античності відомі такі висловлювання, як «філософія дарує людині презирство до смерті» або «завдання філософії - підготувати до смерті», а Ф. Ніцше в «Народженні трагедії з духа музики» зазначав, що взагалі антична культура (традиція, філософія) народжується 3 прагнення подолати трагічність смерті шляхом іiі раціоналізації, «забовтування», від стоїчного «страшна не сама смерть, а ставлення до 
неї як до страшної» до епікурівського «коли ми є, іiі нема, а коли вона є, нас уже нема». Ідея, що усвідомлення власної смертності зробило «людину людиною», повторюється на різни лади від Августина до Гегеля й стала візитною карткою екзистенційної філософії. Узагалі філософська антропологія ХХ ст. характеризується переорієнтацією 3 традиційної ідеї вітальності на ідею тимчасовості, кінцевості, смертності людського існування, тому важко назвати серед сучасних дослідників таких, які б не зверталися до проблеми смерті. Серед філософських студій, які розглядали осягнення цього феномена як актй ідентифікації, висвітлювання й актуалізації власного буття людини, особливо цікавими для нас є роботи С. К’єркегора, М. Гайдегтера, Ж.-П. Сартра, Ж. Дерріди, Ж. Бодрійяра, Ф. Ар'єса, В. Янкелевича, О. Кленіної, М. Трофімова, В. Подогори, М. Шильмана тощо.

Уперше загальний аналіз проблеми ставлення до смерті в західноєвропейській традиції здійснив Філіп Ар’єс у роботі «Людина перед обличчям смерті». Французький дослідник повсякденності запропонував теорію еволюції людства на засадах ставлення до смерті, у якій виділяє п’ять етапів: «смерть приручена», «смерть своя», «смерть далека та близка», «смерть твоя» й «смерть перевернута» [2]. Зміну епох, періодів існування людства можна простежувати за ставленням до смерті. У патріархальну епоху смерть i смертність людини сприймається як природне, необхідне, закономірне явище: усе, що народжується, те й має померти. Смерть $є$ необхідною частиною життя, феноменом повсякденності, а тому не сприймається трагічно й особистісно. Це $\epsilon$ «приручена смерть». Протягом усього життя людину супроводжують ритуали приготування до смерті. Смерть не $\epsilon$ індивідуальним феноменом, тому ритуали націлені на демонстрацію єдності, солідарності з громадою, соціумом тощо. Вона не вириває померлого з родини, спільноти, а лише «переводить» його у інший стан: померлого достатньо довго «збирають в останню путь», читають сакральні тексти, прощаються, а потім вони (померлі) споглядають і захищають живих; кладовища розташовані в межах міста, і там не «вщухає» життя (регулярно відвідують померлих, зустрічаються 3 коханими, обмінюються новинами, навіть крамарюють). Ритуальні дії можуть відрізнятися в культурних традиціях, але загальне ставлення незмінне: смерть уплетена в життя, є його логічним закінченням. У такому суспільстві людина має знати час власної смерті, приготуватися (запросити священика, родичів, написати заповіт тощо), а «ненормальною», поганою вважається смерть раптова, і неважливо, у якому віці.

На другому етапі, який Ф. Ар’єс називає «смерть своя», феномен смерті розглядається як особистісний, тому що, за віруваннями, після смерті людина має відповідати за земне життя (Страшний Суд, Чистилище тощо). Такий перехід філософ пояснює зростанням індивідуальної свідомості, відокремленням себе не тільки від тваринного світу, але й від суспільства. На його думку, «усвідомлення в годину смерті або в думці про смерть своєї власної ідентичності, особистої історії як у цьому світі, так і в іншому» $є$ «відкриттям індивіда», індивідуального власного Я. Уже за період, який назвали «смерть далека та близька», цвинтарі почали переносити за місто (хоча, можливо, спочатку це було більше пов'язане з епідемією чуми), тобто тепер мертві все більше відокремлюються, віддаляються від живих. Близькість із 
мерцями стає все більш нестерпною, а вигляд трупів, скелетів і будь-якої символіки Танатоса, які нещодавно були вагомою частиною мистецтва, поступово замінюються на більш життєстверджувальні, романтичні картини ${ }^{1}$.

На наступному етапі цієї танатологічної еволюції з'являється «смерть твоя», тобто переживання смерті Іншого (близького, коханого, дитини тощо), яка сприймається трагічніше, ніж власна смерть. Феномен смерті визначається як закінчення будь-яких можливостей, як унеможливлення щось змінити, досказати, завершити розпочате... Але водночас із розумінням смерті як трагедії, «непоправної втрати», виникає й iї романтизація - очікування власної смерті як можливості зустрітися, возз'єднатися 3 померлими близькими. Так страх перед іiі обличчям трансформується в певне відчуття прекрасного. Анонімність погребіння поступово зникає, а на надгробках з'являються написи, зображення, епітафії, тобто знакисимволи того, що залишається після людини й буде існувати «замість неї», іноді довше, ніж вона сама у власному житті. Людина «у смерті» прикрашається («dе mortuis aut bene, aut nihil»), виглядає так, якою мала б бути, а не такою, якою стала за життя. Таке ставлення до феномена смерті розкриває класичну парадигму філософсько-антропологічного дискурсу, коли людина розглядається як така, яка має певне визначення та має за життя його реалізувати.

Та, нарешті, п’ятий етап, на думку автора, висвітлює стан сьогодення - «смерть перевернута». Вона повністю відповідає ситуації Постмодерну: тут феномен смерті так само, як і власне суспільство, людина, життя перебувають у площині гри, симуляції, імітації. Ф. Ар’єс уважає, що поступове витіснення смерті з колективної свідомості в наш час досягає апогею. Тема смерті стає настільки затабуйованою, що здається, що взагалі ніхто не помирає $\epsilon^{2}$. Як зазначають сучасні дослідники, ставлення до феномена смерті в постмодерністському суспільстві розгортається в двох протилежних напрямках: 3 одного боку, вона «приховується», а 3 другого «демонструється» [13]. Потужна урбанізація, рухливість життя, збільшення населення, боротьба з хворобами, подовження строків життя в деякому сенсі не залишають для смерті місця, і суспільство, так би мовити, «виганяє» смерть, залишає iï за межами повсякденного дискурсу. Смерть сприймається як перепона, протиставлення життю. Отже, якщо смерть - це трагедія, то життя - це щастя, а тому смерть приховується від суспільства, людей, індивіда ${ }^{3}$, натомість досягнення життя позиціюються. Ставлення до смерті стає таким самим симулякром, як і ставлення до

\footnotetext{
1 У демонстрації символів смерті Ф. Ар'єс убачає свого роду протилежність жаги життя й матеріальних благ, символічне піклування про матеріальне, земне благополуччя.

${ }^{2}$ Смерть «відкрита» була справою соціуму; усе товариство брало участь (прощалися з покійним, готували та проводжали в останню путь, відвідували на цвинтарі тощо. Нині церемонії стають простіші й коротші, усе відбувається непомітно, а старовинний чорний катафалк зі сріблом змінив звичайний похоронний транспорт, який зливається з потоком авто й, у глобальному сенсі, людина просто зникає.

${ }^{3}$ А ті, хто «зустрівся зі смертю», померли, якнайскоріше «вилучаються» 3 суспільства, ними займаються спеціальні служби, скорочується термін прощання з померлим.
} 
всього іншого, вона сприймається як гра; «приховування» смерті в реальному житті замінюється iї повсякчасною демонстрацією на екрані: у кінострічках, новинах, реаліті-шоу. Така «показова» смерть зменшує гостроту осягнення власної смертності в реальному житті, а акцентування уваги на можливості подовжити життя відволікає від питання про його якість, тобто від осмислення й переживання (чи «пере-житія») його неповторності, від необхідності власноруч вибудовувати свій проект, власну Ясамість.

Як було зазначено раніше, ставлення до феномена смерті є символічним кодом, за допомогою якого висвітлюються особливості розуміння сутності людини й суспільства в різні епохи. Якщо придивитися до метафор, якими в сучасності звертаються до цього феномена, то наявним стає певний механіцизм щодо розуміння людини ${ }^{1}$, позбавлення iï духовних засад, які стимулювали іiі життя як єдиного цілого; не як механізму, а як Організму, незавершеної «стохастичної системи», що здатна до саморозвитку й будується за подобою фрактала.

Отже, духовна ситуація сьогодення повною мірою вважається кризовою. «Безгрунтовність», яка, за словами Л. Шестова, мала $б$ «звільнити» неповторну особистість від «влади ключів», соціальних обмежень і необхідностей на користь індивідуальної свободи, відповідальності й сприяти формуванню власної ідентичності, натомість призвела до розповсюдження суспільства постмодерного типу. Гнучкість і нестабільність соціальних та індивідуальних зв'язків, відсутність або розмитість ціннісних орієнтирів, моральних настанов, фундаментальних засад, чіткого розмежовування й визначення на будь-яких рівнях (науково-категоріальному, професійному, етичному, соціальному, гендерному тощо) зумовило таку саму «розмитість» (або механістичну взаємозамінюваність) й на усіх рівнях особистісного простору, позбавило внутрішній світ людини ціннісних засад та орієнтирів. Ситуація сьогодення найчастіше характеризується такими концептуальними поняттями Постмодерну, як «деконструкція», «людина без обличчя», «людина без почуттів», «смерть суб'єкта (автора)» тощо. Це свідчить про глобальні зміни, які відбуваються в духовному вимірі особистості, а саме «обездуховлення», утрату сенсу буття i, як результат, загублення або пошкодження самого життя в екзистенційному розумінні, яке вимагає напруженого його відчуття як «тут-і-зараз», «стурбованість» ним теперішнім. Як було зазначено раніше, ставлення до власної сутності й життя і їх осягнення тісно переплетені з усвідомленням феномена смерті. Саме усвідомлення власної смертності повертає погляд людини на саму себе, потребує самоідентифікації, самовизначення, відповіді на запитання: «Хто Я $€$ ?» Метафорично тільки 3 появою смерті народжується життя, а осягнення власної фізичної (біологічної) смерті може сприяти народженню особистості в екзистенційному розумінні.

Необхідно зауважити, що смерть як феномен людського існування, який супроводжує людину протягом усього життя, може бути розглянута в різних модусах:

\footnotetext{
1 Так, про причини смерті ми говоримо: «відмовили нирки», «зупинилося серце», «не витримали судини», використовуючи суто механістичні терміни.
} 
як фізична, соціальна (як самотність, ізоляція), психологічна (як беземоційність, байдужість), політична, екзистенційна тощо. На кожному 3 них гострота відчуття буття відрізняється, а отже, змінюється й значення цього акту для вибудовування особистісного простору. Найбільш суттєву роль для визначення сутності власного буття, визначеності «Я» відіграє усвідомлення смертності в біологічному (фізичному) та екзистенціальному розуміннях.

Біологічна, тілесна й екзистенційна смерть як втрата, загублення сенсу життя в різних аспектах їх вивчення відрізняються, але тісно пов'язані одна з одною. Перше за все, розрізняють ставлення до власної смертності й смерті інших. В емпіричному вимірі фізична власна смерть нам ніколи не надана, вона завжди попереду, і в цьому розумінні ми зіштовхуємося не зі своєю смертю, а зі смертю інших. Саме, за Ф. Ар'єсом, «смерть твоя», близьких, родичів, коханих лякає нас найбільш, пригнічує своєю незворотністю, розриває буття на шматки «до» і «після», унеможливлює щось змінити, висловити, виявити почуття. Це відчуття неминучості ставить людину перед безоднею, «зазирнувши у яку бачиш, що вона дивиться на тебе» (Олді) і дивиться очима смерті. У темпоральному вимірюванні, якщо переживання власної біологічної смерті завжди попереду, то вболівання смерті Іншого «проглядає з минулого».

Зовсім інша річ із розгляданням феноменів життя та смерті в екзистенційному розумінні, тут вектори існування на різних щаблях змінюються на протилежні. Якщо в біологічному вимірі власне життя відчувається як «присутність» тут-і-зараз, у теперішньому, а смерть завжди «попереду», то в екзистенційному, - навпаки, гостре відчуття недаремності, осмисленості, наповненості життя зазвичай позаду (уже пройшло) або попереду (у сподіваннях), а ось усвідомлення власної екзистенційної смерті миттєве як вибух і може стати «отвором», «ковчегом» в істинне Буття [12]. В екзистенційному плані смерть відчувається як «присутність», тобто «існуванняперед-власною-сутністю». Це зіштовхування цілісного, завершеного «Я-тут-і-зараз» iз «Я-якого-може-не бути» («Я-яким-я-можу-не-стати»). Отже, переживання присутності власної фізичної смерті може спонукати до екзистенційного народження, прагнення до вибудовування проекту власного Я. Усвідомлення смерті як «тут-ізараз» $\epsilon$ тим, що в постмодернізмі називають «розломом» між теперішнім $i$ майбутнім, з якого тільки й може народитися щось нове [5].

В екзистенційному розумінні переживання смерті $\epsilon$ гострим відчуттям присутності Іншого, який «дивиться на мене», споглядає, визначає й від погляду якого я не можу сховатися чи відвернутися. Якщо переповісти Ж.-П.Сартра, «присутність Іншого - це пекло». Але ж у сучасній постмодерністській традиції, де «будь-яка тотожність симульована» [6], а особистість розглядається як «дивід», що уникає визначеності й сталості, людина завжди може сховатися за «масками та ролями», удавати наявність якоїсь ідентичності, тобто видати себе, за кого побажає. Але, на відміну від сартрівського, «Іншого у житті», цього «Іншого-присутнього-усмерті» не можна обдурити; перед ним не можна зіграти, тому що це мій власний погляд, спіткання 3 тією екзистенцією, яку побачать і запам'ятають інші і яку я вже не в змозі буду змінити. Чи згоден я постати саме таким? Чи це і є той проект, якого я прагнув? 
Ми часто вживаємо і вже звикли до вислову «подивитися на себе з боку». Але такий миттєвий (але не одномиттєвий) акт прискіпливого споглядання, який називають «зустріччю» (М. Бубер) чи «діалогом» (М. Бахтін), поставляє «Язавершеного» перед обличчям «Я-можливого» й може виявити ушкодженість екзистенції або відкрити власну екзистенційну смерть, утрату сенсу й перспективи життя. Недарма С. К’єркегор зауважує, що «найгірша небезпека - утрата власного Я може пройти для нас зовсім непомітно», на відміну від втрати ноги, майна, друга тощо [8, с. 383]. Такий акт гострого незадоволення висвітленням власної сутності в існуванні, тобто екзистенції, осягнення втрати сенсу буття або його ціннісних орієнтирів, викликає, за С. К'єркегором, стан відчаю [8, с. 371-373]. Це почуття не може бути частковим (воно охоплює людину повністю) або відносним (не можна зневірятися щодо чогось зовнішнього); це відчай не бути самим собою, не здійснити власний екзистенційний проект. А отже, як влучно зауважує I. Ялом, хоча фізична смерть руйнує людину, але ідея смерті, усвідомлення цього факту як можливого «туті-зараз» може врятувати iї (цит. за [1]).

На відміну від феномена смерті в біологічному плані, екзистенційна смерть не наявна, не наочна, тому скоріше осягається особисто, ніж відкриється Іншому. Так само мені не явлена екзистенційна смерть Іншого, а отже, усвідомлення власної втрати опори й сенсу життя гостріше, ніж те ж саме щодо Іншого. «Зустріч» зі смертю, тобто осягнення смертності, може відкрити гостре незадоволення власним існуванням, прагненням себе змінити. Людина знає про смерть, осягає власну смертність і тому розуміє, що життя є рухом до смерті, ії відкладенням, але ж це дає й вибір. Переживання феномена смерті стає тією «межовою ситуацією», яка може повернути людину до самої себе. Відчуття смерті як «тут-і-зараз» є гострим відчуттям можливості залишитися незмінним, «присутність» себе як сталого, закінченого. А отже, це ставить людину перед вибором: залишитися такою самою назавжди чи спробувати змінити, виправити проект власного життя.

Екзистенціальна філософія розглядає особистість як таку, сутністю існування якої є постійне трансцендування, випадання в Ніщо, Небуття. Вона має завжди бути подана як проект, який має вибудовуватися протягом усього життя, а завершенням якого стає смерть. Будь-яка ідентичність, визначеність, тотожність себе $\epsilon$ нежиттєздатною [3], є тільки одним із щаблів, із яких складається самість, але кожна може стати останньою й визначальною.

Видатний вітчизняний філософ Мирослав Попович в одному зі своїх інтерв'ю сказав: «Поки людина жива, ми не можемо про неї нічого сказати, бо сьогодні вона зробила один учинок, а завтра - зовсім інший і перекреслила все те, що було раніше. Уся людська біографія - це сукупність вчинків. І сенс життя теж стосується усієї цієї сукупності вчинків, останнім з яких є відхід людини». Відчуття неминучості смерті виманює мою самість 3 анонімності й повсякденної зануреності. Осягнення смерті як можливої «тут-і-зараз» стає нагадуванням, що існування, присутність не можна відкласти.

Звертання й осягнення феномена смерті певною мірою можна порівняти 3 фракталом як парадигмальним концептом, тобто безкінечним розгортанням складної 
системи, утворюваної зі схожих елементів, які за структурою подібні самій цілісній системі. Важливішою особливістю фрактала $\epsilon$ те, що це стохастична, тобто невизначена, випадкова структура; вона складається зі схожих, але інваріативних елементів, кожен із яких може вплинути й змінити систему в цілому. Так само можна розглядати й структуру внутрішнього світу особистості, самість як таку, що складається 3 подібних до неї самої елементів - таких собі, «тимчасових», «теперішніх» самостей. Ця система постійно розгортається і $€$ невизначеною до самого кінця (тобто до смерті), адже кожен іiі елемент схожий, але не тотожний попередньому. Будь-який учинок, подія, самоідентифікація, визначеність «тут-ізараз» можуть стати визначальними, такими, що змінять усю структуру внутрішнього світу особистості, цілісну самість. «Дивитися на світ «через» смерть означає дивитися на все $з$ погляду вічності...» [4, с. 304], там, де сама думка, так би мовити, розтягується.

«Я-фрактал»- це сукупність різноманітних феноменів Я, уявлень особистості про себе, власних ідентифікацій, споглядань Іншого, які врешті-решт поєднаються в єдине ціле. Зустріч із собою, «вдивляння в себе теперішнього» немов перед обличчям смерті повертає до якогось певного Я, «тут-і-зараз», у цілісності різноманітних проявів; такого Я, якого більш не буде, але яке може залишитися таким назавжди, у незмінності. Смерть може застати людину в будь-який час, щомиті. Вона «помножується й диференціюється, щоб представити (репрезентувати) життю одиничності.... Життя відтепер полягає в тому, щоб зайняти своє місце, займати всі свої місця в кортежі під назвою "вмирання"» [4, с. 304]. У кожній із цих митей Я постає певною цілісністю, одиницею, яка, своєю чергою, складається 3 безлічі феноменів прожитого життя, переживань, почуттів, думок, незавершених проектів... I кожна 3 таких «зустрічей», якщо відбудеться, може змінити цілісну структуру Я, витворити новий екзистенційний проект, змінити життя, розгорнути власний «Яфрактал».

Отже, якщо в класичній парадигмі в розгляді сутності людини увага акцентувалася на визначеності іiі сутнісних ознак, тобто зумовленості існування певними обставинами (соціальними детермінантами, божественним походженням тощо), то сучасність скоріше розглядає піi як таку, що розпадається на безліч епіфеноменів, розшаровується у власній невизначеності, що призводить до втрати осмисленості власного буття, позбавляє його сенсу, а саму людину завершеності й самості. За таких обставин актуальним є дослідження таких феноменів буття людини, які б могли актуалізувати і1і життя, «повернути до нього обличчям». Одним із таких найсуттєвіших актів є осягнення власної смертності як можливої «тут-і-зараз», гостре усвідомлення, що будь-якої миті проект твого власного життя може стати незворотньо завершеним, відкриття самого себе таким, як є, у цілісності проявлених феноменів. Сутність особистості в екзистенційному сенсі складає постійне трансцендування, вихід за межі визначеності, відкритість світу, постійний діалог. У цьому діалозі екзистенція постає і як початок, «вихідна точка», і як перспектива, можливість. Смерть $є$ завершенням будь-яких проектів, можливостей. «Незнамо де й незнамо коли очікує на нас смерть, так нумо жити так, немов вона поруч...» [10]. 
Тому осягнення феномена смерті (як можливого «тут-і-зараз») $є$ знаходженням обличчям до обличчя до власної «тут-і-зараз сутності», «зустріччю» із однією 3 «тимчасових самостей». Екзистенційна ідентичність складається 3 безлічі «тимчасових» самостей, кожна 3 яких може стати визначальною й останньою. Людина як «Я-фрактал» розгортає можливі проекти, ідентифікації себе. I в цьому розумінні осягнення власної смертності може стати екзистенційним народженням, переходом до вищих рівнів буття. Людина як «Я-фрактал» $\epsilon$ стохастичною, невизначеною системою до самого іiі завершення, а отже, і змінити завершену Ясамість можна будь-якої миті.

\section{Література :}

1. Абросимова E. А. Анализ концепций смерти в философии С. Кьеркегора и М. Хайдеггера. URL : http://hpsy.ru/public/x009.htm

2. Арьес $\Phi$. Человек перед лицом смерти. URL: https://www.ereading.club/book.php?book=148384

3. Бодрийяр Ж. Символический обмен и смерть. URL: https://www.ereading.club/book.php?book=102635

4. Губин В. Д. Смерть - «единственная надежда быть человеком». // Homophilosophans. Серия «Мыслители». Вып. 12. СПб. : Санкт-Петербургское философское общество, 2002. С. 303-311.

5. Дельоз Ж. Фуко. URL : http://booksonline.com.ua/view.php?book=76850

6. Деррида Ж. Дар Смерти // Вісник Харківського національного університету ім. В. Н. Каразіна. Серія: Теорія культури і філософія науки. 2003. № 579/1. С. 3-25.

7. Кленина $E$. А., Песков A. E. Отношение к смерти как условие формирования различных типов культур // Вестник АГТУ, 2015, № 1. С. 73-76.

8. Кьеркегор С. Болезнь к смерти // Этическая мысль: Науч.-публицист. чтения. М. : Политиздат, 1990. С. 361-470.

9. Мамардашвили М. Необходимость себя. URL : http://psylib.org.ua/books/mamar02/txt01.htm

10. Монтень M. O том, что философствовать - это значит учиться умирать. URL : https://lib.misto.kiev.ua/FILOSOF/MONTEN/death.dhtml

11. Николаева E. В. От ризомы и складки к фракталу. URL: https://cyberleninka.ru/article/n/otrizomy-i-skladki-k-fraktalu

12. Хайдеггер $M$. Бытие иремя. URL : https ://imwerden.de/pdf/heidegger_vremya_i_bytie_1993.pdf

13. Шильман M.E. Каково восприятие смерти в современном обществе. URL: https ://www.youtube.com/watch?v=oHfXCUCucSU

\section{References:}

1. Abrosimova, E. A. (2011). Analiz kontseptsiy smerti v filosofii S. Kerkegora i M. Haydeggera [Analysis of the concepts of death in the philosophy of S. Kierkegaard and M. Heidegger], available at : http://hpsy.ru/public/x009.htm

2. Ares F. Chelovek pered litsom smerti [Human in face of death], available at: https://www.ereading.club/book.php? book $=148384$

3. Baudrillard, J. Simvolicheskiy obmen $i$ smert [Symbolic Exchange and Death], available at : https://www.e-reading.club/book.php?book=102635

4. Gubin, V. D. (2002). Smert - «edinstvennaya nadezhda byit chelovekom» [Death is "the only hope of being human"'], St. Petersburg: Homophilosophans.

5. Deloz, J. Fuko [Foucault], available at : http://booksonline.com.ua/view.php?book=76850 
6. Derrida, Zh. (2003). Dar Smerti [Dar Death], Kharkiv: VIsnik HarkIvskogo natsIonalnogo unIversitetu im. V. N. KarazIna.

7. Klenina, E. A., Peskov, A. E. (2015) Otnoshenie k smerti kak uslovie formirovaniya razlichnyih tipov kultur [Attitude towards death as a condition for the formation of various types of cultures]. Vestnik AGTU.

8. Kerkegor, S. (1990). Bolezn k smerti [Illness to death]. Moskow : Politizdat.

9. Mamardashvili, M. Neobhodimost sebya [Necessity of oneself], available at : http://psylib.org.ua/books/mamar02/txt01.htm.

10. Monten, M. O tom, chto filosofstvovat - eto znachit uchitsya umirat [About the fact that philosophizing - it means learning to die], available at : https://lib.misto.kiev.ua/FILOSOF/MONTEN/death.dhtml.

11. Nikolaeva, E. V. (2014). Ot rizomyi i skladki $k$ fraktalu [From rhizomi and folds to fractal], available at : https://cyberleninka.ru/article/n/ot-rizomy-i-skladki-k-fraktalu.

12. Haydegger M. Byitie $i$ vremya [Being and Time], available at: https://imwerden.de/pdf/heidegger_vremya_i_bytie_1993.pdf.

13. Shilman, M. E. Kakovo vospriyatie smerti v sovremennom obschestve [What is the perception of death in modern society], available at : https://www.youtube.com/watch? $v=o H f X C U C u c S U$

\section{Natalia Bilchuk, Anastasiia Bilchuk}

\section{COMPREHENSION OF THE PHENOMENON OF DEATH AS EXISTENTIAL PERSONAL IDENTITY}

Modern philosophical anthropology reveals more and more complicated structure of a person's inner world. While in the classic paradigm when reviewing the essence of a human the attention was paid to the importance of the person's essential features, that is to the existence of certain circumstances (social determinants, divine origin, etc...), contemporary science considers it as something that splits into many epihpenomas, stratifies in its own ambiguity, which brings it to losing meaningfulness of the personal existence, takes away its objective reality and comprehension of its own existence and its self-completeness.

In such circumstances, it is relevant to study the phenomena of human existence, which could update its life, «turn it face to face» with its life and itself. A human is the only creature, whose being is not determined by the fact of birth («to be a human» is not the same as «to belong to biological species»). It is transcendence that goes beyond the limits of the biological sphere and opens the existential dimension of the personality and forms the «humaneness in a human being».

The essence of a person acts like «indefinite-definite»: while he / she is alive nothing is known for sure about him/ her and when death comes, it's impossible to change anything. Life consists of many events, phenomena of existence, «singularities», «temporal identities», which together form a single integrity. Each of the «here-and-now» phenomena of life can affect a personal «I» as a whole and change it.

In this sense, self-consciousness can be considered as the analogy of the fractal, as eye visualization of the idea of «chaotic» complexity, endless formation and incompleteness of many socio-cultural phenomena, that is, it is considered a stochastic system. The essence of the personality in the existential sense is constant transcendence, going out of the bounds of certainty, openness to the world, constant dialogue, etc. In this dialogue, the existence 
means both the beginning, or the «starting point», and a prospect, or an opportunity. Death is the end of any projects and opportunities.

«We do not know where and when death awaits us, so let's live as if it were near...» It is the comprehension of the phenomenon of death, death here and now that can annually determine its own certainty, opens to the person its own self in the unity, integrity of the manifestations of the phenomena. Therefore, the comprehension of the phenomenon is death (unavoidable and possible here and now) comes into collision with «here and now essence», «a meeting dialogue» with one of the «temporary self-independence». This is the dialogue between what you are now and what you would like to be. An essential feature of an individual, an existential identity consists of a set of «temporary» identities, each of which can become primordial and final. A person as «I-fractal» unfolds possible projects, self-identification. So, in this sense, the attainment of one's own mortality can become an existential birth, a transition to higher levels of being. Human as «I-fractal» is a stochastic, indefinite system until its completion, and hence the change of completed Selfindependence can be over at any time.

Keywords: existential death, self, «I-fractal», presence.

\section{Наталя Більчук, Анастасія Більчук}

\section{ОСЯГНЕННЯ ФЕНОМЕНА СМЕРТІ ЯК ЕКЗИСТЕНЦЙНА ІДЕНТИЧНІСТЬ ОСОБИСТОСТІ}

Сучасна філософська антропологія розкриває все більш ускладнену структуру внутрішнього світу особистості. Якщо в класичній парадигмі в розгляді сутності людини увага акцентувалася на визначеності їі сутнісних ознак, тобто зумовленості існування певними обставинами (соціальними детермінантами, божественним походженням тощо), то сучасність скоріше розглядає їі як таку, що розпадається на безліч епіфеноменів, розшаровується у власній невизначеності, що призводить до втрати осмисленості власного буття, позбавляє його сенсу, а саму людину завершеності й самості.

За цих обставин актуальним є дослідження таких феноменів буття людини, які б могли актуалізувати iі життя, «повернути до нього обличчям». Людина є єдиною істотою, чия сутність не визначається фактом народження («бути людиною» не тотожне «належати до біологічного виду»). Саме трансцендування, вихід за межі біологічного й відкриває екзистенційний вимір особистості, формує «людяне у людині».

Людина постає «невизначено-визначеною»: поки вона жива, про неї нічого невідомо достеменно, а коли прийде смерть, вона вже нічого не може змінити. Життя складається 3 безлічі подій, феноменів існування, «одиничностей», «тимчасових самостей», які разом мають об'єднатися у єдину цілісність. Кожен із «тут-і-зараз» феноменів життя може впливати на особистісне Я як єдине ціле, змінити його. У цьому розумінні самість можна розглядати за аналогією 3 фракталом - наочною демонстрацією систем «хаотичної» складності, які перебувають у нескінченному 
становленні й виражають незавершений характер соціокультурних феноменів, а отже, $\epsilon$ стохастичними системи. Сутність особистості в екзистенційному розумінні становить постійне трансцендування, вихід за межі визначеності, відкритість світу, постійний діалог. У цьому діалозі екзистенція постає і як початок, «вихідна точка», i як перспектива, можливість. I тільки явлення смерті стає завершенням будь-яких проектів і можливостей.

Тому осягнення феномена смерті (як можливого «тут-і-зараз») є перебуванням обличчям до обличчя до власної «тут-і-зараз сутності», «зустріччю» 3 однією 3 «тимчасових самостей». Це діалог із собою, яким ти є зараз, із тим, яким ти хотів би бути. Така «зустріч», якщо вона відбудеться, стає «присутністю», тобто знаходженням «перед-сутністю». Сутнісна ознака особистості, екзистенційна ідентичність складається 3 безлічі «тимчасових» самостей, кожна 3 яких може стати визначальною й останньою. Людина як «Я-фрактал» розгортає можливі проекти, ідентифікації себе. I в цьому розумінні осягнення власної смертності може стати екзистенційним народженням, переходом до вищих рівнів буття. Людина як «Яфрактал» є стохастичною, невизначеною системою до самого їі завершення, а отже, «зустріч» із власною «перед-сутністю» може змінити завершену Я-самість. Отже, як казали любомудри, «memento mori».

Ключові слова: екзистенциійна смерть, самість, «Я-фрактал», присутність.

Bilchuk Natalia - Candidate of Philosophy. Associate Professor. Heard of the Department of Philosophy of the National Aerospace University «Kharkiv Aviation Institute».

Більчук Наталя - кандидат філософських наук, доцент, виконувач обов'язків завідувача кафедри філософії Національного аерокосмічного університету ім. М.Є. Жуковського «Харківський авіаційний інститут».

e-mail: n.bilchuk@khai.edu

Bilchuk Anastasiia - Postgraduate of the Department of Philosophy of the National Aerospace University «Kharkiv Aviation Institute».

Більчук Анастасія - аспірант кафедри філософії Національного аерокосмічного університету ім. М.С. Жуковського «Харківський авіаційний інститут».

...Для мене, випускниці історичного факультету Харківського державного університету імені В.Н. Каразіна, філософи й усі, хто знається на філософії, викладає ї̈, завжди здавалися якимись «небожителями»: недосяжними, особливими, але загадково цікавими. На той час фахової освіти з філософії в Харкові не було, а аспірантуру в ХАI відкрили. Я довго вагалася, та коли дізналася, щзо вступають два випускники ХАІ з технічних факультетів, також вирішила ризикнути й відразу потрапила в привітну й доброзичливу атмосферу, яку створював навколо себе тоді завідувач кафедри, професор Кім Олексійович Байрачний. Його завжди усміхнене обличчя, батьківська турбота про кожного аспіранта чи співробітника разом із високим професіоналізмом, незвичайною обізнаністю, гостротою розуму навіювали думки, щзо все буде гаразд $i$ «не святі горщзики ліплять». Трохи згодом стало зрозуміло, щчо така атмосфера - відмінна риса всієї кафедри. Звісно, не все виходило з 
першого разу: перші заняття зі студентами (які тільки трохи молодші за мене), перші виступи перед викладачами кафедри... Але завжди відчувалась підтримка, співчуття й повага. Саме після першої доповіді на кафедрі (до речі, провальної) мені запропонувала допомогу Євгенія Петрівна Корогодова, висококваліфікований фахівець, досвідчений викладач, чуйна й водночас вимоглива людина. Вона розважливо й терпляче допомагала «народжувати» мені кандидатську, опікувалася викладацькою діяльністю, ставши «науковою матір'ю». Я дуже вдячна всім викладачам кафедри, які створили й підтримують до тепер ичей Дух Філософіï.

Більчук Наталя Леонідівна, кандидат філософських наук, доцент, виконувач обов’язків завідувача кафедри філософії. Після закінчення історичного факультету Харківського національного університету працює на кафедрі філософії вже двадцять років, тобто пройшла шлях від асистента до виконувача обов'язків завідувача кафедри. На цій кафедрі вчилася в аспірантурі й готувала дисертацію під науковим керівництвом Байрачного К. О.

Надійшла до редакції 19.02.2019. Розглянута на редколегії 18.03.2019.

\section{Рецензенти:}

Доктор філософських наук, професор кафедри філософії Національного аерокосмічного університету ім. М.С. Жуковського «ХАІ» Кузнецов А.Ю.

Кандидат філологічних наук, доцент, доцент кафедри документознавства та української мови Національного аерокосмічного університету ім. М.С. Жуковського «ХАI» Медведь О.В. 